\title{
Informal eldercare and care for disabled children in the Nordic countries: prevalence and relation to employment
}

\author{
Niklas Jakobsson \\ Norwegian Social Research (NOVA) \\ Email: nja@nova.no
}

\section{Andreas Kotsadam}

Norwegian Social Research (NOVA)

Email:ako@nova.no

\section{Marta Szebehely}

Department of Social Work

Stockholm University

Email: marta.szebehely@socarb.su.se

\begin{abstract}
In an international comparison, the Nordic countries are generous care spenders and a relatively large proportion of the populations receive formal care services. However, in respect of service provision, the Nordic countries are less similar today than they were some decades ago. Using survey data from three Nordic countries, Denmark, Norway, and Sweden, we first document the differences in informal care between the countries, and then we assess its impact on the relationship between informal caregiving and formal employment.
\end{abstract}


We find that informal care is most common in Denmark and least common in Sweden. However, those who provide care in Sweden provide care more often than people in both Norway and Denmark. There is a negative correlation between being a caregiver and the probability of being employed in Norway and Denmark, but not in Sweden. With specific regard to parental care, there is no general relation between the provision of parental care and employment, but those providing substantial care are clearly less likely to work than others. Caring for a disabled child is less common than caring for a parent, but the negative effects on employment are even stronger.

Keywords: care, eldercare, informal care, disabled children, employment

\section{Introduction}

Informal care is widely acknowledged to affect paid employment, but the main focus in the work-life balance discourse is on childcare (Ackers, 2003; Crompton \& Lyonette, 2006; Leira, 2006). This aspect is well exemplified in the policy debate in Europe (see Ackers, 2003 for an overview), where there are concerns about the effects of an aging population on the tax burden of the working-age population (Rubery et al., 2001). If the time devoted to informal eldercare is negatively associated with female employment, it is a fact that merits consideration in discussions on eldercare and especially on the reliance on informal care. Furthermore, if different institutions and policies change the impact of informal care on female employment, then the results can serve as a basis for further policy discussions. The literature on Nordic childcare and employment focuses on healthy children (e.g., Leira, 2006), and care of disabled children may be an important complement as it is likely to be more time-demanding even if it is less common. Hence, this article is situated in the debates on work-life balance and makes two central contributions regarding the scope of the type of care studied. First, it considers informal eldercare, which is very common among working-age people. Secondly, it 
considers the care of disabled children, which is potentially more timedemanding than is the care of healthy children.

In the literature on the welfare state, the Nordic countries are wellknown for their de-familializing and universal approach to welfare, where services are paid by all and are available for all based on individual need and are to the same standards (Esping-Andersen \& Korpi 1987; Kautto et al., 1999). Some of the central principles of universalism in care services include the objectives of offering services according to need and not purchasing power and making the same services affordable for the poor but still attractive for the better off (Szebehely, 2005). It seems to be the case that caregiving to older people has less of an effect on employment in the Nordic welfare states than in the rest of Europe, but the data used is becoming outdated (Bolin et al., 2008; Kotsadam, 2011; 2012). Moreover, it is questionable whether these countries can really still be grouped together. Rauch (2007) compares childcare and eldercare services in six European countries and questions the assumption that the Scandinavian countries constitute a coherent model. He makes two distinct and important points: welfare states differ internally across different types of care provision, and even within, for example, eldercare the Scandinavian countries differ between each other a lot.

In the present article we investigate how different patterns of caregiving are related to employment in three Nordic countries, Denmark, Norway, and Sweden. We focus on differences in caregiving and on the links between informal caregiving and formal employment. Our aims are to describe the differences in informal caregiving between the countries and to see if there is a relationship between being an informal caregiver and formal employment. We contribute to the literature by investigating both the relationships between informal eldercare and employment in the Nordic countries, and the relationships between care of disabled children and employment. The first aspect is important because most studies have only investigated the relationship in Anglo-Saxon countries. The second is important due to the lack of focus on disability care in the employment literature and the lack of comparative studies across the Nordic countries in this respect. Comparing informal care for older and disabled people is potentially important because care services for 
these two groups tend to differ even in the same country. A Swedish study that has compared informal caregiving for disabled adults and frail older people suggests that those helping a disabled person under the age of 65 provide more hours of care and receive less support from the formal care services than do those caring for a parent or another relative 65 years or older (Jeppsson Grassman et al., 2009).

We find that provision of informal care (including all types of care) is most common in Denmark and least common in Sweden. However, those who provide care in Sweden provide care more often than people in both Norway and Denmark. There is a negative correlation between being a caregiver and the probability of being employed in Norway and Denmark, but not in Sweden. In regard to parental care (i.e., eldercare), there is no general relationship between providing parental care and employment, but those providing substantial care for a parent or for a disabled child are clearly less likely to work than others.

This article proceeds as follows. In Section 2 we review the previous literature on the relationship between informal caregiving and employment. In Section 3 we describe the differences and similarities in care systems in the three countries, with respect to both formal and informal caregiving, and present our hypotheses. In Section 4 we describe the data used and present descriptive differences between the countries. Section 5 presents the results regarding the differences in informal caregiving and the relationship between informal caregiving and employment. Section 6 concludes the article with a general discussion about the implications of the results and the limitations of the data.

\section{Previous studies on the link between informal caregiving and employment}

The previous evidence on the effects of informal care on employment outcomes is mixed, and the institutional context seems to be important. Most of the existing studies on the relationship between informal care and employment-related outcomes do not differentiate 
between care for older people and for disabled children or adults. The majority of these studies have been carried out in the United States (e.g., Ettner, 1996; Johnson \& Lo Sasso 2000; Lilly et al., 2007; Pavalko \& Artis, 1997; Wolf \& Soldo, 1994; ) and the United Kingdom (Carmichael \& Charles, 1998; 2003a; 2003b; Carmichael et al., 2004; 2008; 2010; Heitmueller, 2007; Heitmueller \& Inglis, 2004; 2007; Michaud et al., 2010). In the UK, there are large cross-sectional differences between caregivers and non-caregivers in employment (e.g., Carmichael \& Charles 1998; 2003a) and wages (Heitmueller \& Inglis, 2007). These differences persist for co-residential and highintensity caregivers in dynamic longitudinal fixed-effects analyses as well (Carmichael et al., 2010; Heitmueller, 2007; Michaud et al., 2010). In the US, Ettner (1996) similarly finds negative effects on the number of hours worked for co-residential caregivers, and Johnson and Lo Sasso (2000) find, investigating men and women aged 53-65, that informal eldercare reduces the number of hours worked, whereas Wolf and Soldo (1994) find no effects of parental caregiving among married women on the reduction in number of hours worked or the probability of being employed. Leigh (2010) uses Australian panel data from 2001 to 2007 and finds an effect of caregiving on labour force participation but not on wages. Thus, there are negative effects of informal caregiving on labour outcomes in the Anglo-Saxon liberal welfare states, especially for high-intensity caregivers.

Outside the Anglo-Saxon countries there exists much less evidence on the relationship between informal care and work. To gain knowledge on the role of institutional factors in mediating the relationship between work and care, studies from other contexts are crucial. Three previous studies compare groups of European countries (Bolin et al., 2008; Kotsadam, 2011; Spiess \& Schneider 2003;). Spiess and Schneider (2003) use a difference in differences approach on two waves of data from the European Community Household Panel (ECHP) to see how changes in caregiving hours (for an older, disabled or chronically ill adult) affect changes in number of weekly work hours for women aged 45-59. They find that starting a caregiving spell reduces the number of hours worked for women in countries with well-developed formal care. However, they find no significant association between changes in care intensity and changes in the number of hours worked in this group. For women in countries 
with less formal care, starting a caregiving spell is negatively correlated with changes in working hours, and there is a strong association between increased caregiving hours and a reduced number of work hours. The divergent results across the two groups are interpreted as indicating more formal care leading to more possibilities of choice and thereby smaller adverse effects. Bolin et al. (2008) focus specifically on care for an older parent and use the first wave of data from the Survey of Health, Ageing and Retirement in Europe (SHARE) from 1994. These authors divide the total sample into three groups: Nordic, Central European, and South European. The main hypothesis is that the adverse effects of parental caregiving on labour supply are stronger in the Nordic group since family care is less accepted in these states, leading to fewer acceptances among, say, employers. Considering the employment probability and number of hours worked for persons aged 55 and over, they find that care has a larger negative effect in Central European countries, but that wages are less affected in this group. Contrary to Bolin et al., (2008), Kotsadam (2011) argues that the effects should be lowest in the Nordic group and highest in the South European group due to the greater availability of formal care and less coercive gendered care norms in the former group. He finds, using the ECHP, that while being a female caregiver in the Nordic countries is not related to employment, it greatly reduces the number of hours worked and the probability of being employed in the South European group. These results are somewhat reinforced in Kotsadam (2012), where he finds in Norway no effects of being an informal caregiver in general, as opposed to providing substantial care. Similar findings are reported from Sweden (Szebehely, 2006).

Hence, while there is a clear negative effect of providing substantial care on employment in Anglo-Saxon welfare states, much less is known about the relationship in other contexts. It seems to be the case that caregiving to frail older people or other adults has less of an effect in the Nordic welfare states, yet the data used is becoming out of date, and another important issue concerns whether these countries can really still be grouped together. Furthermore, it has not been analysed whether informal care for disabled children and for older people have similar consequences for women's and men's employment. In the present article we investigate how different

NJSR - Nordic Journal of Social Research

Vol. 4, 2013 
patterns of caregiving are related to employment in three Nordic countries, Denmark, Norway, and Sweden. We focus on describing differences in informal caregiving and in the links between employment and informal caregiving for older parents and for disabled children in the three countries.

\section{Care in the Nordic countries and hypotheses}

In a much cited article, Anttonen and Sipilä (1996) compare the proportions of elderly over 65 who receive institutional care or home help across 14 European countries, and conclude that there is a Scandinavian model of public services in which eldercare services are widely available. Universalism is the guiding principle, which means that women benefit and members of the middle class use the services, which in turn facilitates public funding. There is also a familycare model (consisting of Portugal, Spain, Greece, and Italy) characterized by a limited supply of social-care services. A third, Central European model is also identified (Germany, the Netherlands and, to a lesser degree, France and Belgium) where the responsibility for eldercare formally falls on the family. In these countries, religious and other organizations provide a large range of services and the state has the main responsibility for funding. The volume of eldercare services is at an intermediate level, except in the Netherlands where it is high. The differences in quality of formal eldercare services are great across countries and also follow the north-south dimension. The level of education and skills required are lowest in the South European countries, highest in the Nordic countries, while the Central European countries are placed in between (Anxo \& Fagan, 2005; Simonazzi 2008).

Although there are similarities between the Nordic countries, there are also crucial differences between them. In an international comparison, all three countries are generous spenders and a relatively large proportion of the populations receive care services (Huber et al. 2009: p. 74, 99). However, in terms of service provision, the Nordic countries are less similar today than they were some decades ago. Of the three countries, Denmark stands out as reaching the largest proportion of the older population with home care services (twice the proportion 
compared with Sweden), while Norway has far more places in residential care than the other two countries. Taking the two forms of care services together, the Danish eldercare services cover the largest and the Swedish eldercare services the smallest proportion of older people (see Table 1).

Table 1. Eldercare provision in Denmark, Norway, and Sweden

\begin{tabular}{llll}
\hline & Denmark & Norway & Sweden \\
Eldercare expenditure as \% of GDP (1) & 1.7 & 1.6 & 2.4 \\
Share of population aged 80 years+ (2) & 4.1 & 4.5 & 5.4 \\
In residential care (65 years+) (3) & 4.9 & 9.7 & 6.4 \\
Home-care recipients (65 years+) (3) & 17.6 & 10.8 & 9.2 \\
Eldercare total (65 years+) & 22.5 & 20.5 & 15.6
\end{tabular}

Sources: 1. Huber et al. 2009: p. 99; 2. Nososco 2009: p. 24; 3. Nososco 2009: pp. 160-161.

On the other hand, those who receive home care in Sweden receive more help than recipients in the other countries: on average, an older Danish home-care recipient receives 3.7 hours of help per week compared to seven hours per week in Sweden (NBHW, 2009; Statistics Denmark, 2011;). In Norway, on average an older person receives 4.4 hours of home care and home nursing combined per week (Statistics Norway, 2010).

There are some studies on the prevalence of care, and especially parental care in the Nordic countries. These studies are usually not straightforwardly comparable since the kinds of care or help they include differ, and of course also due to differences in samples. In Norwegian data from the early 1990s, Lingsom (1994) finds that about 16 per cent of children over 40 years of age provided care for their parents regularly. In Norwegian data from 2007-2008 (Herlofson, 2012), 18 per cent of children provide care for their parents at least once a month. On the basis of the 1992-1993 Eurobarometer survey, Alber and Köhler $(2004$, p. 60,63$)$ find that 25 per cent of Danish adults provided care for a family member or friend who was ill, disabled or old (17 per cent cared for an older person and four per 
cent for a disabled child); in Sweden the corresponding figures were 27, 19, and seven per cent, respectively. Using data from the SHARE survey, Ogg and Renaut (2006) find that about 40 per cent of the sample in Denmark and Sweden (all above 50 years of age) provide some eldercare (Norway is not included in this dataset). In all, there seems to be a lot of variation in the findings regarding the prevalence of informal care.

As fewer older persons receive formal care services in Sweden than in Denmark, we would expect the families of frail older people to provide more care in Sweden. A recent analysis of sources of care among older people in Denmark and Sweden points in the same direction: significantly more older people in need of care in Sweden report that they receive help from children and other family members or friends (help from spouses not included) (Rostgaard \& Szebehely, 2012). However, as the Danish services are less intensive, it may be the case that informal care is more intensive in Denmark.

Our research questions are:

- How common is it that men and women in the three Nordic countries provide regular care to parents, disabled children, and other dependents?

- Does the link between informal caregiving and formal employment differ between the three countries?

\section{Data and descriptive statistics}

In August 2010, TNS Gallup was hired to send out an Internet-based survey to a random sample of 4500 Danes, 4500 Norwegians, and 3252 Swedes aged 18-65. In total, 6164 out of the 12252 responded (50.3 per cent). ${ }^{1}$ The respondents had three weeks to answer the survey and received three reminders. The multi-purpose survey included questions about informal care, employment, and demographics such as gender, age, and education.

\footnotetext{
${ }^{1}$ The total comprised 2088 (46.4 per cent) Danes, 1705 (52.4 per cent) Swedes, and 2371 (52.7 per cent) Norwegians.
} 


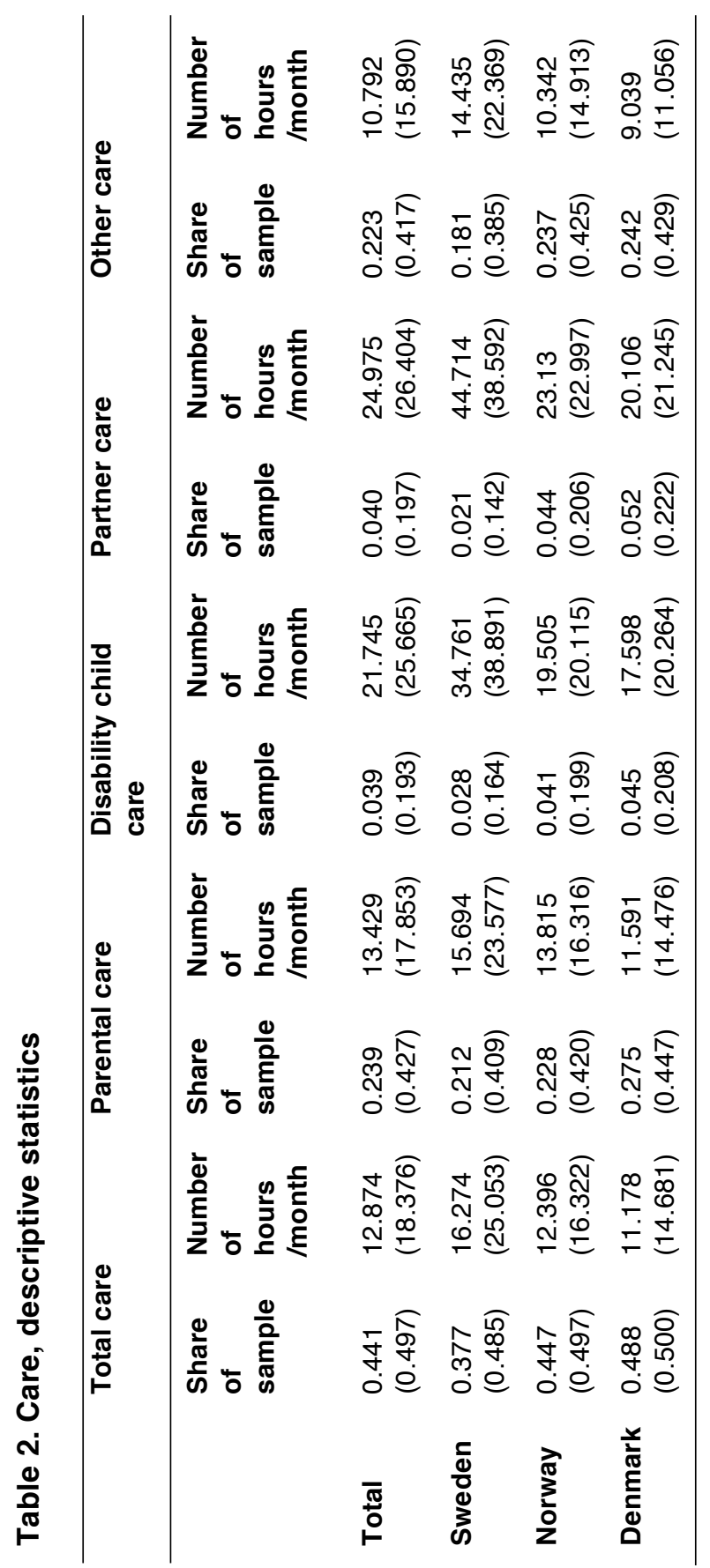

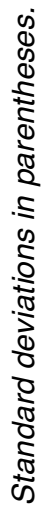

NJSR - Nordic Journal of Social Research 
Table 2 presents descriptive statistics of the data on caregiving. We present data on the shares of the sample providing different types of care, as well as the mean number of care hours for those providing care. Even though there are clear differences in demographic factors between the countries (Table A1 in Appendix 1), we start by describing the differences regarding the care variables before we turn to a more formal analysis in Section 5 .

The central survey question on informal care provision posed to the respondents was: 'Have you helped a family member, relative, friend, or neighbour who needs help in everyday life owing to long-term illness, disability, or old age at least once a month during the past year (e.g., with cleaning, paper work, personal care, or going outside)?' A respondent is considered to provide care (the column marked Total care in Table 2) if he or she provides care within at least one of the following categories: Parental care, Child care, Partner care, or Other care. First, considering caregiving in general (Total care), the results indicate that a large share of the sample provides some kind of informal care on a regular basis: 49 per cent in Denmark, 45 per cent in Norway, and 38 per cent in Sweden. These numbers seem very high, but many of the respondents only provide care for a very limited number of hours. Fifty-eight per cent of those who provide care provide less than ten hours of care a month. The share providing monthly parental care (24 per cent) is somewhat higher than the numbers presented in other studies (e.g., Alber \& Köhler 2004; Herlofson, 2012; ), but lower than the numbers reported in the SHARE survey (see, e.g., Ogg \& Renaut, 2006). Care for a disabled child is much less frequent (four per cent), slightly lower than indicated in previous studies such as Alber and Köhler (2004) and Jeppsson Grassman et al., (2009). Finally, the share of respondents who provide care to others (a relative, friend, or neighbour) at least once a month is as high as the share providing parental care (22 per cent), which seems very high, but is in line with the findings from a Swedish survey (Jegermalm \& Jeppsson Grassman, 2009). One possible reason for comparatively high proportions of caregivers in this study could be that the question asked includes a wide range of tasks (e.g., cleaning, paperwork, personal care, or going outside), not only the more demanding aspects of family caregiving, such as personal care. 
Turning to the average number of hours of care provided per month, Swedes provide 16 hours, Norwegians 12 hours, and Danes 11 hours. In all the three countries, those providing care for a disabled child provide more hours of care than those who care for a parent or another relative or friend. Table A2 in Appendix 1 gives variable descriptions for all the variables used in this article; the questions on care posed to the respondents are presented in Appendix 2.

Table 3. Descriptive statistics, by the extent of care input

\begin{tabular}{llll}
\hline Variable & Non-care & Care & Substantial care \\
\hline Age & 41.853 & 47.126 & 48.200 \\
Married & $(13.512)$ & $(13.069)$ & $(12.415)$ \\
& 0.687 & 0.716 & 0.740 \\
Employed & $(0.464)$ & $(0.451)$ & $(0.440)$ \\
& 0.743 & 0.723 & 0.694 \\
Male & $(0.437)$ & $(0.447)$ & $(0.462)$ \\
& 0.507 & 0.4805 & 0.434 \\
Capital & $(0.500)$ & $(0.500)$ & $(0.500)$ \\
& 0.200 & 0.162 & 0.187 \\
High income & $(0.400)$ & $(0.368)$ & $(0.391)$ \\
& 0.092 & 0.100 & 0.119 \\
Low income & $(0.289)$ & $(0.300)$ & $(0.324)$ \\
& 0.158 & 0.135 & 0.145 \\
High education & 0.495 & 0.467 & 0.506 \\
& $(0.500)$ & $(0.500)$ & $(0.501)$ \\
Low education & 0.097 & 0.093 & 0.094 \\
& $(0.297)$ & $(0.291)$ & $(0.292)$ \\
\hline
\end{tabular}

Standard deviations in parentheses. 
Table 3 presents descriptive statistics for the categories Non-care, Care, and Substantial care, where 'substantial carer' refers to those providing at least 30 hours of care per month (4.4 per cent of the population). These carers are particularly interesting to investigate since they spend a substantial amount of time caring for others. Noncarers are younger, less likely to be married, more likely to be employed, and more likely to be men. The table clearly shows that especially those providing substantial amounts of care are less likely to be employed than both non-caregivers and caregivers in general. Since the characteristics of these three groups differ in so many other ways (e.g., age, civil status, and gender), these findings should be interpreted with caution. In Section 5 we turn to a more formal analysis of caregivers and non-caregivers, but first a few words on the representativeness of our data.

Our sample is fairly representative with regard to both gender and age, whereas with education it is biased towards highly educated people. Moreover, there are serious concerns regarding the nonrandom rate of response. Although this aspect should be considered when comparing raw correlations and mean values, we can somewhat alleviate the problem in the regression analyses by explicitly controlling for education and other confounding factors. For a more detailed description of the representativeness of the data, see Jakobsson and Kotsadam (2010; 2011) and Kotsadam and Jakobsson (2011).

\section{Results}

As seen in the descriptive statistics above, there are some clear differences across these countries. We also know our country samples differ in composition. We therefore move on to analyse the relationships explored in the previous section, controlling for potential confounding differences between the countries. 
Table 4. Parental care and substantial care

\begin{tabular}{|c|c|c|c|c|}
\hline VARIABLES & $\begin{array}{l}1) \\
\text { Care } \\
\end{array}$ & $\begin{array}{l}(2) \\
\text { Care } \\
\end{array}$ & $\begin{array}{l}\text { (3) } \\
\text { Substantial care }\end{array}$ & $\begin{array}{l}\text { (4) } \\
\text { Substantial care }\end{array}$ \\
\hline Sweden & $\begin{array}{l}-0.061^{\star \star \star} \\
(0.013)\end{array}$ & $\begin{array}{l}-0.050^{\star \star \star} \\
(0.013)\end{array}$ & $\begin{array}{l}-0.015^{\star \star} \\
(0.006)\end{array}$ & $\begin{array}{l}-0.013^{\star \star} \\
(0.006)\end{array}$ \\
\hline Norway & $\begin{array}{l}-0.045^{\star \star \star} \\
(0.012)\end{array}$ & $\begin{array}{l}-0.008 \\
(0.013)\end{array}$ & $\begin{array}{l}0.006 \\
(0.006)\end{array}$ & $\begin{array}{l}0.010 \\
(0.006)\end{array}$ \\
\hline Male & & $\begin{array}{l}-0.050^{* * *} \\
(0.011)\end{array}$ & & $\begin{array}{l}-0.010^{* *} \\
(0.005)\end{array}$ \\
\hline Capital & & $\begin{array}{l}-0.036^{\star * *} \\
(0.014)\end{array}$ & & $\begin{array}{l}-0.006 \\
(0.006)\end{array}$ \\
\hline High income & & $\begin{array}{l}0.018 \\
(0.019)\end{array}$ & & $\begin{array}{l}0.010 \\
(0.010)\end{array}$ \\
\hline Low income & & $\begin{array}{l}0.006 \\
(0.018)\end{array}$ & & $\begin{array}{l}0.014 \\
(0.009)\end{array}$ \\
\hline High education & & $\begin{array}{l}-0.032^{\star * *} \\
(0.012)\end{array}$ & & $\begin{array}{l}0.004 \\
(0.005)\end{array}$ \\
\hline Low education & & $\begin{array}{l}-0.007 \\
(0.020)\end{array}$ & & $\begin{array}{l}0.008 \\
(0.010)\end{array}$ \\
\hline Married & & $\begin{array}{l}0.040^{\star * *} \\
(0.012)\end{array}$ & & $\begin{array}{l}0.004 \\
(0.006)\end{array}$ \\
\hline Age & & $\begin{array}{l}0.018^{* * *} \\
(0.003)\end{array}$ & & $\begin{array}{l}0.000 \\
(0.001)\end{array}$ \\
\hline $\mathrm{Age}^{2}$ & & $\begin{array}{l}-0.000^{\star \star \star} \\
(0.000)\end{array}$ & & $\begin{array}{l}0.000 \\
(0.000)\end{array}$ \\
\hline Observations & 6164 & 6164 & 6164 & 6164 \\
\hline
\end{tabular}

Standard errors in parentheses. ${ }^{* \star *} p<0.01,{ }^{* \star} p<0.05,{ }^{*} p<0.1$. Marginal effects after probit regressions.

Differences in informal eldercare

We start by considering the differences between individuals in the three countries with regard to parental caregiver status. Table 4 presents marginal effects after probit regressions. In Columns 1 and 2 , the dependent variable is whether the respondent provides parental care or not. When controlling for confounding factors, we see that being a caregiver is least common in Sweden, and the difference between Norway and Denmark is not statistically significant. These 
results are also very similar for the other types of caregivers (results available upon request). In Columns 3 and 4, substantial care (i.e., providing at least 30 hours of care per month) is the dependent variable; the results here also indicate that this practice is least common in Sweden. These findings are contrary to our hypotheses, to wit, that informal eldercare provision should be more common in Sweden than in Norway and Denmark.

We now turn to investigating how much eldercare (in terms of how many hours of care to an elderly parent or parent-in-law per month) is provided and whether this is something that differs across the countries. The first column of Table 5 shows the raw difference across countries. Denmark is the excluded country, so the number of care hours in Denmark is given by the constant term. We see that Danes give an average of 11.59 hours of parental care per month, whereas Swedes give about four hours more and the Norwegians place in between, giving two more hours per month than the Danes. These relations hold fairly well when we control for confounding factors in Column 2, which is important as we do not want the country differences simply to reflect compositional factors. In Columns 3 to 5 we split the sample by country in order to examine possible country differences in the determinants of care hours. The highly educated and those with a low income in Denmark provide more care than others; this is not the case in Norway and Sweden. Danish men do not provide less eldercare than Danish women, contrary to the case in Norway and Sweden. Living in the Danish capital (Copenhagen) is associated with providing less care, while living in the other capitals (Oslo and Stockholm) is associated with providing more care. The effect of age is insignificant in Denmark, as opposed to in Norway and Sweden. Being married is associated with providing less care, but the coefficient is only statistically significant in Sweden. The findings for parental care are very similar to the results for care in general (not shown here). 
Table 5. Parental-care hours

\begin{tabular}{|c|c|c|c|c|c|}
\hline VARIABLES & $\begin{array}{l}\text { (1) } \\
\text { No controls }\end{array}$ & $\begin{array}{l}(2) \\
\text { Controls }\end{array}$ & $\begin{array}{l}\text { (3) } \\
\text { Sweden }\end{array}$ & $\begin{array}{l}(4) \\
\text { Norway }\end{array}$ & $\begin{array}{l}\text { (5) } \\
\text { Denmark }\end{array}$ \\
\hline Sweden & $\begin{array}{l}4.103^{\star * *} \\
(1.204)\end{array}$ & $\begin{array}{l}3.861^{\star * *} \\
(1.204)\end{array}$ & & & \\
\hline Norway & $\begin{array}{l}2.224^{\star *} \\
(1.080)\end{array}$ & $\begin{array}{l}2.631^{\star *} \\
(1.098)\end{array}$ & & & \\
\hline Male & & $\begin{array}{l}-3.311^{* * *} \\
(0.957)\end{array}$ & $\begin{array}{l}-4.501^{*} \\
(2.502)\end{array}$ & $\begin{array}{l}-4.071^{\star * *} \\
(1.467)\end{array}$ & $\begin{array}{l}-1.542 \\
(1.306)\end{array}$ \\
\hline Capital & & $\begin{array}{l}3.365^{\star *} \\
(1.363)\end{array}$ & $\begin{array}{l}8.156^{\star *} \\
(3.183)\end{array}$ & $\begin{array}{l}6.298^{\star *} \\
(2.488)\end{array}$ & $\begin{array}{l}-1.565 \\
(1.716)\end{array}$ \\
\hline High income & & $\begin{array}{l}-0.299 \\
(1.556)\end{array}$ & $\begin{array}{l}-0.585 \\
(4.511)\end{array}$ & $\begin{array}{l}-0.444 \\
(2.280)\end{array}$ & $\begin{array}{l}-0.521 \\
(2.053)\end{array}$ \\
\hline Low income & & $\begin{array}{l}4.075^{\star *} \\
(1.617)\end{array}$ & $\begin{array}{l}5.703 \\
(4.316)\end{array}$ & $\begin{array}{l}0.606 \\
(2.511)\end{array}$ & $\begin{array}{l}6.363^{\star * *} \\
(2.081)\end{array}$ \\
\hline High education & & $\begin{array}{l}0.123 \\
(1.000)\end{array}$ & $\begin{array}{l}-0.900 \\
(2.683)\end{array}$ & $\begin{array}{l}-1.742 \\
(1.503)\end{array}$ & $\begin{array}{l}2.482^{*} \\
(1.331)\end{array}$ \\
\hline Low education & & $\begin{array}{l}0.128 \\
(1.792)\end{array}$ & $\begin{array}{l}-0.797 \\
(4.263)\end{array}$ & $\begin{array}{l}0.379 \\
(3.421)\end{array}$ & $\begin{array}{l}0.770 \\
(2.236)\end{array}$ \\
\hline Married & & $\begin{array}{l}-1.820 \\
(1.121)\end{array}$ & $\begin{array}{l}-2.675 \\
(2.877)\end{array}$ & $\begin{array}{l}-2.698 \\
(1.665)\end{array}$ & $\begin{array}{l}-0.728 \\
(1.572)\end{array}$ \\
\hline Age & & $\begin{array}{l}-0.358 \\
(0.280)\end{array}$ & $\begin{array}{l}-1.470 \\
(0.904)\end{array}$ & $\begin{array}{l}-0.699^{*} \\
(0.403)\end{array}$ & $\begin{array}{l}0.266 \\
(0.362)\end{array}$ \\
\hline $\mathrm{Age}^{2}$ & & $\begin{array}{l}0.005^{\star} \\
(0.003)\end{array}$ & $\begin{array}{l}0.016 \\
(0.010)\end{array}$ & $\begin{array}{l}0.010^{\star *} \\
(0.005)\end{array}$ & $\begin{array}{l}-0.002 \\
(0.005)\end{array}$ \\
\hline Constant & $\begin{array}{l}11.59^{\star \star *} \\
(0.755)\end{array}$ & $\begin{array}{l}17.86^{\star \star \star} \\
(6.256)\end{array}$ & $\begin{array}{l}50.98^{\star *} \\
(20.90)\end{array}$ & $\begin{array}{l}26.56^{\star \star \star} \\
(8.716)\end{array}$ & $\begin{array}{l}4.710 \\
(8.070)\end{array}$ \\
\hline Observations & 1446 & 1446 & 360 & 531 & 555 \\
\hline $\mathrm{R}^{2}$ & 0.008 & 0.033 & 0.047 & 0.056 & 0.027 \\
\hline
\end{tabular}


In this section we have described the differences in parental caregiving in Norway, Sweden, and Denmark. We have shown that giving such informal eldercare is most common in Denmark and least common in Sweden. However, those who provide care in Sweden provide more care than do people in both Norway and Denmark.

Country differences in the relationship between informal care and employment

We have seen that there are differences in parental caregiving between the countries and that these differences persist even when we control for factors at the individual level. But do these differences also imply that there are differences in the relationship between caregiving and work? In Table 6 we investigate the relationship between being a caregiver (i.e., all types of caregivers) and being employed. In Column 1, no controls are added and we see that the caregivers are about two percentage points less likely than noncaregivers to be employed. In Column 2, we see that the relationship is actually stronger once we control for confounding variables. Looking at the three countries separately, as is done in Columns 3 to 5 , we see that the effect is only statistically significant in Norway and Denmark. The difference between Sweden and the other countries is also statistically significant (results not presented). Looking at those who provide substantial care (more than 30 hours per month), we also find a negative effect of care provision (Column 6) (no statistically significant country differences, results available upon request). Hence, the conclusion is that there is a quite strong negative correlation between being a caregiver and the probability of being employed in Norway (4.5 percentage points) and Denmark (5.0 percentage points) but not in Sweden, even when we control for individual-level variables. 
Table 6. Care and employment

\begin{tabular}{|c|c|c|c|c|c|c|}
\hline \multirow[b]{2}{*}{ VARIABLES } & \multirow{2}{*}{$\begin{array}{l}1) \\
\text { Basic }\end{array}$} & \multirow{2}{*}{$\begin{array}{l}\text { (2) } \\
\text { With } \\
\text { controls }\end{array}$} & \multirow{2}{*}{$\begin{array}{l}\text { (3) } \\
\text { Sweden }\end{array}$} & \multirow{2}{*}{$\begin{array}{l}\text { (4) } \\
\text { Norway }\end{array}$} & \multirow{2}{*}{$\begin{array}{l}\text { (5) } \\
\text { Denmark }\end{array}$} & \multirow{2}{*}{$\begin{array}{l}6) \\
\text { Substantial } \\
\text { care }\end{array}$} \\
\hline & & & & & & \\
\hline \multirow[t]{2}{*}{ Care } & $-0.019^{*}$ & $-0.033^{\star * *}$ & -0.002 & $-0.045^{\star \star}$ & $-0.050^{\star *}$ & $-0.075^{\star \star}$ \\
\hline & $(0.011)$ & $(0.013)$ & $(0.021)$ & $(0.022)$ & $(0.023)$ & (0.032) \\
\hline Male & & $\begin{array}{l}-0.003 \\
(0.013)\end{array}$ & $\begin{array}{l}-0.011 \\
(0.020)\end{array}$ & $\begin{array}{l}-0.023 \\
(0.022)\end{array}$ & $\begin{array}{l}0.023 \\
(0.024)\end{array}$ & $\begin{array}{l}-0.003 \\
(0.013)\end{array}$ \\
\hline Capital & & $\begin{array}{l}0.023 \\
(0.016)\end{array}$ & $\begin{array}{l}0.005 \\
(0.026)\end{array}$ & $\begin{array}{l}0.000 \\
(0.030)\end{array}$ & $\begin{array}{l}0.033 \\
(0.027)\end{array}$ & $\begin{array}{l}0.023 \\
(0.016)\end{array}$ \\
\hline \multirow[t]{2}{*}{ High income } & & 0.008 & $-0.184^{\star \star \star}$ & 0.026 & $0.181^{\star \star \star}$ & 0.009 \\
\hline & & (0.022) & $(0.050)$ & $(0.036)$ & $(0.030)$ & (0.022) \\
\hline \multirow[t]{2}{*}{ Low income } & & $-0.588^{\star \star \star}$ & $-0.554^{\star \star \star}$ & $-0.608^{\star \star \star}$ & $-0.598^{\star * *}$ & $-0.586^{\star \star \star}$ \\
\hline & & $(0.019)$ & $(0.037)$ & $(0.030)$ & (0.032) & $(0.019)$ \\
\hline \multirow{2}{*}{$\begin{array}{l}\text { High } \\
\text { education }\end{array}$} & & $0.042^{\star \star \star}$ & -0.014 & $0.071^{* \star *}$ & 0.035 & $0.043^{\star \star *}$ \\
\hline & & $(0.013)$ & $(0.022)$ & $(0.023)$ & $(0.024)$ & $(0.013)$ \\
\hline \multirow{2}{*}{$\begin{array}{l}\text { Low } \\
\text { education }\end{array}$} & & $-0.094^{\star \star \star}$ & $-0.094^{\star *}$ & $-0.105^{\star}$ & $-0.110^{* *}$ & $-0.093^{\star * *}$ \\
\hline & & $(0.026)$ & (0.039) & $(0.057)$ & $(0.043)$ & $(0.026)$ \\
\hline Married & & $\begin{array}{l}0.038^{\star \star *} \\
(0.014)\end{array}$ & $\begin{array}{l}-0.006 \\
(0.021)\end{array}$ & $\begin{array}{l}0.090^{\star \star \star} \\
(0.025)\end{array}$ & $\begin{array}{l}0.034 \\
(0.026)\end{array}$ & $\begin{array}{l}0.038^{\star \star *} \\
(0.014)\end{array}$ \\
\hline Age & & $\begin{array}{l}0.076^{\star \star \star} \\
(0.003)\end{array}$ & $\begin{array}{l}0.055^{\star \star \star} \\
(0.006)\end{array}$ & $\begin{array}{l}0.073^{\star \star \star} \\
(0.006)\end{array}$ & $\begin{array}{l}0.093^{\star \star \star} \\
(0.006)\end{array}$ & $\begin{array}{l}0.076^{\star \star \star} \\
(0.003)\end{array}$ \\
\hline \multirow[t]{2}{*}{$\mathrm{Age}^{2}$} & & $-0.001^{\star \star \star}$ & $-0.001^{\star \star \star}$ & $-0.001^{\star \star \star}$ & $-0.001^{* * *}$ & $-0.001^{\star \star *}$ \\
\hline & & (0.000) & $(0.000)$ & $(0.000)$ & $(0.000)$ & $(0.000)$ \\
\hline Sweden & & $\begin{array}{l}0.130^{\star \star \star} \\
(0.014)\end{array}$ & & & & $\begin{array}{l}0.132^{\star \star \star} \\
(0.014)\end{array}$ \\
\hline Norway & & $\begin{array}{l}0.008 \\
(0.015)\end{array}$ & & & & $\begin{array}{l}0.010 \\
(0.015)\end{array}$ \\
\hline Observations & 6105 & 6105 & 1704 & 2325 & 2076 & 6112 \\
\hline
\end{tabular}

Standard errors in parentheses. ${ }^{* \star *} p<0.01,{ }^{* *} p<0.05,{ }^{*} p<0.1$. Dependent variable: Employed. Marginal effects after probit regressions.. 
We now move on to investigate the relationship between parental care and employment in the same fashion as above. The results are presented in Table 7 . In Column 1, we actually note a positive correlation between being a caregiver and being employed. Once we control for confounding variables, however, the relationship is not statistically significant (Column 2). These results are in accord with the results in Kotsadam (2011) which demonstrate that there are no effects of providing informal eldercare on the probability of being employed in the Nordic welfare states, and with Kotsadam (2012) that shows the provision of eldercare in general (as opposed to providing substantial amounts of care) in Norway is not related to employment. There are no statistically significant differences between the countries in the relationship between being an informal eldercare giver in general and employment (results are available upon request), and we note that the correlation is not statistically different from zero in any of the countries (Columns 3 to 5 ). However, looking at those who provide substantial eldercare (more than 30 hours per month), we find a negative effect of providing care (Column 6). This is in line with the results from previous research on Norway (Kotsadam, 2012). Again, there are no country differences with respect to this correlation (results are available upon request).

Turning to the relations between care for disabled children and employment, we can see the results in Table 8. In contrast to parental care, we note a negative relationship between employment and childcare in the total sample (Column 2). We find an even larger effect of substantial childcare but no statistically significant differences between the countries (Column 6). 
Table 7. Parental care and employment

\begin{tabular}{|c|c|c|c|c|c|c|}
\hline VARIABLES & $\begin{array}{l}(1) \\
\text { Basic }\end{array}$ & $\begin{array}{l}(2) \\
\text { With } \\
\text { controls }\end{array}$ & $\begin{array}{l}\text { (3) } \\
\text { Sweden }\end{array}$ & $\begin{array}{l}\text { (4) } \\
\text { Norway }\end{array}$ & $\begin{array}{l}(5) \\
\text { Denmark }\end{array}$ & $\begin{array}{l}(6) \\
\text { Substantial } \\
\text { care }\end{array}$ \\
\hline $\begin{array}{l}\text { Parental } \\
\text { care }\end{array}$ & $\begin{array}{l}0.049^{\star * *} \\
(0.013)\end{array}$ & $\begin{array}{l}-0.002 \\
(0.015)\end{array}$ & $\begin{array}{l}0.027 \\
(0.024)\end{array}$ & $\begin{array}{l}-0.026 \\
(0.026)\end{array}$ & $\begin{array}{l}0.010 \\
(0.026)\end{array}$ & $\begin{array}{l}-0.090^{\star *} \\
(0.042)\end{array}$ \\
\hline Male & & $\begin{array}{l}-0.002 \\
(0.013)\end{array}$ & $\begin{array}{l}-0.010 \\
(0.020)\end{array}$ & $\begin{array}{l}-0.023 \\
(0.022)\end{array}$ & $\begin{array}{l}0.027 \\
(0.024)\end{array}$ & $\begin{array}{l}-0.003 \\
(0.012)\end{array}$ \\
\hline Capital & & $\begin{array}{l}0.024 \\
(0.016)\end{array}$ & $\begin{array}{l}0.004 \\
(0.026)\end{array}$ & $\begin{array}{l}0.000 \\
(0.030)\end{array}$ & $\begin{array}{l}0.037 \\
(0.027)\end{array}$ & $\begin{array}{l}0.023 \\
(0.016)\end{array}$ \\
\hline High income & & $\begin{array}{l}0.007 \\
(0.022)\end{array}$ & $\begin{array}{l}-0.186^{\star \star \star} \\
(0.050)\end{array}$ & $\begin{array}{l}0.025 \\
(0.036)\end{array}$ & $\begin{array}{l}0.181^{* * *} \\
(0.030)\end{array}$ & $\begin{array}{l}0.007 \\
(0.022)\end{array}$ \\
\hline Low income & & $\begin{array}{l}-0.588^{\star \star \star} \\
(0.019)\end{array}$ & $\begin{array}{l}-0.554^{\star \star \star} \\
(0.037)\end{array}$ & $\begin{array}{l}-0.603^{\star \star \star} \\
(0.031)\end{array}$ & $\begin{array}{l}-0.599^{\star \star \star} \\
(0.032)\end{array}$ & $\begin{array}{l}-0.587^{\star \star \star} \\
(0.019)\end{array}$ \\
\hline $\begin{array}{l}\text { High } \\
\text { education }\end{array}$ & & $\begin{array}{l}0.043^{\star \star \star} \\
(0.013)\end{array}$ & $\begin{array}{l}-0.013 \\
(0.022)\end{array}$ & $\begin{array}{l}0.070^{\star \star \star} \\
(0.023)\end{array}$ & $\begin{array}{l}0.038 \\
(0.024)\end{array}$ & $\begin{array}{l}0.043^{\star \star \star} \\
(0.013)\end{array}$ \\
\hline $\begin{array}{l}\text { Low } \\
\text { education }\end{array}$ & & $\begin{array}{l}-0.094^{\star \star *} \\
(0.026)\end{array}$ & $\begin{array}{l}-0.093^{\star \star} \\
(0.039)\end{array}$ & $\begin{array}{l}-0.107^{*} \\
(0.057)\end{array}$ & $\begin{array}{l}-0.109^{\star \star} \\
(0.043)\end{array}$ & $\begin{array}{l}-0.093^{\star \star \star} \\
(0.026)\end{array}$ \\
\hline Married & & $\begin{array}{l}0.038^{\star * *} \\
(0.014)\end{array}$ & $\begin{array}{l}-0.007 \\
(0.021)\end{array}$ & $\begin{array}{l}0.089^{* * *} \\
(0.025)\end{array}$ & $\begin{array}{l}0.032 \\
(0.027)\end{array}$ & $\begin{array}{l}0.038^{* * *} \\
(0.014)\end{array}$ \\
\hline Age & & $\begin{array}{l}0.076^{\star \star \star} \\
(0.003)\end{array}$ & $\begin{array}{l}0.055^{\star \star \star} \\
(0.006)\end{array}$ & $\begin{array}{l}0.073^{\star \star *} \\
(0.006)\end{array}$ & $\begin{array}{l}0.092^{* * *} \\
(0.006)\end{array}$ & $\begin{array}{l}0.077^{\star \star \star} \\
(0.003)\end{array}$ \\
\hline $\mathrm{Age}^{2}$ & & $\begin{array}{l}-0.001^{\star * \star} \\
(0.000)\end{array}$ & $\begin{array}{l}-0.001^{\star \star \star} \\
(0.000)\end{array}$ & $\begin{array}{l}-0.001^{\star \star \star} \\
(0.000)\end{array}$ & $\begin{array}{l}-0.001^{\star \star *} \\
(0.000)\end{array}$ & $\begin{array}{l}-0.001^{\star * *} \\
(0.000)\end{array}$ \\
\hline Sweden & & $\begin{array}{l}0.132^{\star \star \star} \\
(0.014)\end{array}$ & & & & $\begin{array}{l}0.132^{\star \star \star} \\
(0.014)\end{array}$ \\
\hline Norway & & $\begin{array}{l}0.009 \\
(0.015)\end{array}$ & & & & $\begin{array}{l}0.010 \\
(0.015)\end{array}$ \\
\hline Observations & 6112 & 6112 & 1705 & 2329 & 2078 & 6112 \\
\hline
\end{tabular}

Standard errors in parentheses. ${ }^{\star \star *} p<0.01,{ }^{\star *} p<0.05,{ }^{\star} p<0.1$. Dependent variable: Employed. Marginal effects after probit regressions.

NJSR - Nordic Journal of Social Research 
Table 8. Care for disabled children and employment

\begin{tabular}{|c|c|c|c|c|c|c|}
\hline VARIABLES & $\begin{array}{l}(1) \\
\text { Basic }\end{array}$ & $\begin{array}{l}(2) \\
\text { With } \\
\text { controls }\end{array}$ & $\begin{array}{l}\text { (3) } \\
\text { Sweden }\end{array}$ & $\begin{array}{l}(4) \\
\text { Norway }\end{array}$ & $\begin{array}{l}\text { (5) } \\
\text { Denmark }\end{array}$ & $\begin{array}{l}(6) \\
\text { Substantial } \\
\text { care } \\
\end{array}$ \\
\hline Childcare & $\begin{array}{l}-0.049 \\
(0.031)\end{array}$ & $\begin{array}{l}-0.072^{\star \star} \\
(0.034)\end{array}$ & $\begin{array}{l}-0.097 \\
(0.072)\end{array}$ & $\begin{array}{l}-0.067 \\
(0.055)\end{array}$ & $\begin{array}{l}-0.056 \\
(0.055)\end{array}$ & $\begin{array}{l}-0.153^{*} \\
(0.081)\end{array}$ \\
\hline Male & & $\begin{array}{l}-0.002 \\
(0.013)\end{array}$ & $\begin{array}{l}-0.011 \\
(0.020)\end{array}$ & $\begin{array}{l}-0.022 \\
(0.022)\end{array}$ & $\begin{array}{l}0.026 \\
(0.023)\end{array}$ & $\begin{array}{l}-0.00 \\
(0.013)\end{array}$ \\
\hline Capital & & $\begin{array}{l}0.023 \\
(0.016)\end{array}$ & $\begin{array}{l}0.004 \\
(0.026)\end{array}$ & $\begin{array}{l}0.001 \\
(0.030)\end{array}$ & $\begin{array}{l}0.035 \\
(0.027)\end{array}$ & $\begin{array}{l}0.023 \\
(0.016)\end{array}$ \\
\hline High income & & $\begin{array}{l}0.008 \\
(0.022)\end{array}$ & $\begin{array}{l}-0.181^{\star * *} \\
(0.050)\end{array}$ & $\begin{array}{l}0.024 \\
(0.036)\end{array}$ & $\begin{array}{l}0.182^{\star * \star} \\
(0.029)\end{array}$ & $\begin{array}{l}0.009 \\
(0.022)\end{array}$ \\
\hline Low income & & $\begin{array}{l}-0.587^{\star * \star} \\
(0.019)\end{array}$ & $\begin{array}{l}-0.551^{\star \star \star} \\
(0.037)\end{array}$ & $\begin{array}{l}-0.603^{\star \star \star} \\
(0.031)\end{array}$ & $\begin{array}{l}-0.598^{\star \star *} \\
(0.032)\end{array}$ & $\begin{array}{l}-0.586^{\star \star \star} \\
(0.019)\end{array}$ \\
\hline $\begin{array}{l}\text { High } \\
\text { education }\end{array}$ & & $\begin{array}{l}0.044^{\star \star \star} \\
(0.013)\end{array}$ & $\begin{array}{l}-0.013 \\
(0.022)\end{array}$ & $\begin{array}{l}0.071^{\star * *} \\
(0.023)\end{array}$ & $\begin{array}{l}0.039 \\
(0.024)\end{array}$ & $\begin{array}{l}0.043^{\star \star \star} \\
(0.013)\end{array}$ \\
\hline $\begin{array}{l}\text { Low } \\
\text { education }\end{array}$ & & $\begin{array}{l}-0.093^{\star \star \star} \\
(0.026)\end{array}$ & $\begin{array}{l}-0.093^{\star \star} \\
(0.039)\end{array}$ & $\begin{array}{l}-0.109^{*} \\
(0.057)\end{array}$ & $\begin{array}{l}-0.108^{\star *} \\
(0.043)\end{array}$ & $\begin{array}{l}-0.094^{\star \star \star} \\
(0.026)\end{array}$ \\
\hline Married & & $\begin{array}{l}0.038^{\star * \star} \\
(0.014)\end{array}$ & $\begin{array}{l}-0.006 \\
(0.021)\end{array}$ & $\begin{array}{l}0.089^{* \star *} \\
(0.025)\end{array}$ & $\begin{array}{l}0.034 \\
(0.026)\end{array}$ & $\begin{array}{l}0.038^{\star * *} \\
(0.014)\end{array}$ \\
\hline Age & & $\begin{array}{l}0.076^{\star \star \star} \\
(0.003)\end{array}$ & $\begin{array}{l}0.055^{\star \star \star} \\
(0.006)\end{array}$ & $\begin{array}{l}0.073^{\star \star \star} \\
(0.006)\end{array}$ & $\begin{array}{l}0.092^{\star \star \star} \\
(0.006)\end{array}$ & $\begin{array}{l}0.077^{\star * *} \\
(0.003)\end{array}$ \\
\hline $\mathrm{Age}^{2}$ & & $\begin{array}{l}-0.001^{\star * \star} \\
(0.000)\end{array}$ & $\begin{array}{l}-0.001^{* * *} \\
(0.000)\end{array}$ & $\begin{array}{l}-0.001^{* \star *} \\
(0.000)\end{array}$ & $\begin{array}{l}-0.001^{\star \star \star} \\
(0.000)\end{array}$ & $\begin{array}{l}-0.001^{\star * \star} \\
(0.000)\end{array}$ \\
\hline Sweden & & $\begin{array}{l}0.131^{\star \star *} \\
(0.014)\end{array}$ & & & & $\begin{array}{l}0.132^{\star \star \star} \\
(0.014)\end{array}$ \\
\hline Norway & & $\begin{array}{l}0.009 \\
(0.015)\end{array}$ & & & & $\begin{array}{l}0.010 \\
(0.015)\end{array}$ \\
\hline Observations & 6112 & 6112 & 1705 & 2329 & 2078 & 6112 \\
\hline
\end{tabular}

Standard errors in parentheses. ${ }^{\star \star \star} p<0.01,{ }^{\star \star} p<0.05,{ }^{\star} p<0.1$. Dependent variable: Employed. Marginal effects after probit regressions.

NJSR - Nordic Journal of Social Research 


\section{Conclusion}

It seems to be the case that informal eldercare has less of an effect on employment in the Nordic welfare states than in other Western countries, yet the data on which this notion is based is becoming timeworn (Kotsadam, 2011; 2012). Furthermore, it is questionable whether these countries can really still be grouped together. There is also a relationship between formal and informal care in the sense that more informal care is provided in areas with less formal care, also within welfare states (Jakobsson et al., 2012). Yet even at a more basic level the relation is intertwined as the very fact that makes care 'informal' is the existence of formal care institutions. In periods and places without formal care, there is just care. Our analysis addresses this issue by providing results from a context with extensive formal care services. It is also important because it does not lump the Nordic countries together into a single model and it differentiates between different types of care provisions. This is the first study investigating the relationship between informal care for disabled children and employment across countries.

In this article we have shown that informal care is most common in Denmark and least common in Sweden. However, those who provide care in Sweden provide more care than do people in both Norway and Denmark.

There is also a large negative correlation between being a caregiver and the probability of being employed in Norway (4.5 percentage points) and Denmark (5.0 percentage points) even when we control for individual-level variables, but not in Sweden. With regard to parental care, there is no general relationship between the provision of parental care and employment, yet those providing substantial amounts of care are clearly less likely to work than others. The situation is similar but stronger for care of disabled children.

So, why do we find a non-negligible relationship between the provision of informal care and not being employed in Denmark and Norway but not in Sweden? Since the relationship is present also when controlling for confounding factors, the difference is not due to differences in observed characteristics between the samples. However, we cannot 
say that the relationship is causal in the sense that starting to provide care in Denmark and Norway causally reduces the likelihood of formal employment. It may very well be the case that people with a weaker relationship to the labour market are more likely to be informal caregivers in Denmark and Norway than in Sweden.

The findings of the present article contribute to several ongoing academic and policy debates. In contrast to studies from Anglo-Saxon countries, informal eldercare in general is not found to be negatively correlated with employment. This highlights the importance of context in analysing the effects of informal care and hints at the importance of formal care for the effects of informal care. For people who provide a lot of informal care either to parents or disabled children, however, there is a negative relation to employment, and this fact is important to consider when making policy choices. We also show that it is important to analyse the different Nordic countries separately and that discussing 'the Nordic model' may mask important heterogeneity. Future studies should investigate both whether the relationship we find is causal and why there are differences between the different countries regarding different types of care. As welfare policies are a result of political struggles, it would be interesting to investigate the political organization of eldercare and disability-care advocates in the different countries.

\section{Acknowledgements}

The research reported in this article was supported by a grant from the Research Council of Norway (project EqualCare 196425/V50), which is gratefully acknowledged. We would also like to thank Thomas Hansen, Kristin Koløen, and seminar participants at Norwegian Social Research for useful comments and suggestions.

\section{References}

Ackers, P. (2003). The Work-Life Balance from the Perspective of Economic Policy Actors. Social Policy and Society, 2(3), 221-229. 
Alber, J., \& Köhler, U. (2004). Health and care in an enlarged Europe. European Foundation for the Improvement of Living and Working Conditions. Luxembourg: Office for Official Publications of the European Communities.

Anttonen, A., \& Sipilä, J. (1996). European Social Care Services: Is It Possible to Identify Models? Journal of European Social Policy, 6(2), 87-100.

Anxo, D., \& Fagan, C. (2005). The Family, the State, and Now the Market the Organisation of Employment and Working Time in Home Care Services for the Elderly. In G. Bosch (Ed.), Working in the Service Sector: A Tale from Different Worlds (pp. 133-164). New York: Routledge.

Bolin, K., Lindgren, B., \& Lundborg, P. (2008). Your next of kin or your own career? Caring and working among the $50+$ of Europe. Journal of Health Economics, 27(3), 718-738.

Carmichael, F., \& Charles, S. (1998). The Labour Market Costs of Community Care. Journal of Health Economics, 17(6), 747-765.

Carmichael, F., \& Charles, S. (2003a). Benefit Payments, Informal Care and Female Labour Supply. Applied Economics Letters, 10(7), 411-415.

Carmichael, F., \& Charles, S. (2003b). The Opportunity Costs of Informal Care: Does Gender Matter? Journal of Health Economics, 22(5), 781803.

Carmichael, F., Conell, G., Hulme, C., \& Sheppard, S. (2004). Who Cares and at What Cost? The Incidence and the Opportunity Costs of Informal Care. Management and Management Science Research Institute Working Paper 209/05, University of Salford.

Carmichael, F., Hulme, C., Sheppard, S., \& Conell, G. (2008). Work-Life Imbalance: Informal Care and Paid Employment in the UK. Feminist Economics, 14(2), 3-35.

Crompton, R., \& Lyonette, C. (2006). Work-Life 'Balance' in Europe. Acta Sociologicia, 49(4), 379-393.

Ettner, S. (1996). The Opportunity Costs of Elder Care. Journal of Human Resources, 31(1), 189-205.

Esping-Andersen, G., \& Korpi, W. (1987). From poor relief to institutional welfare states. In R. Erikson, E. J. Hansen, S. Ringen, \& H. Uusitalo 
(Eds.), The Scandinavian Model (pp. 39-74). Armonk (NY): M. E. Sharpe.

Heitmueller, A. (2007). The Chicken or the Egg? Endogeneity in Labor Market Participation of Informal Carers in England. Journal of Health Economics 26(3), 536-559.

Heitmueller, A., \& Inglis, K. (2004). Carefree? Participation and Pay Differentials for Informal Carers in Britain. Institute for the Study of Labor (IZA) Discussion Paper 1273.

Heitmueller, A., \& Inglis, K. (2007). The Earnings of Informal Carers: Wage Differentials and Opportunity Costs. Journal of Health Economics 26(4), 821-841.

Herlofson, K. (2012). Hjelp til foreldre fra voksne barn - kjønnsroller på glid eller i stillstand? [Help to parents with adult children: gender roles about to change or in standstill?] Unpublished manuscript.

Huber, M., Rodrigues, R., Hoffmann, F., Gasior, K., \& Marin, B. (2009). Facts and Figures on Long-Term Care - Europe and North America. Vienna: European Centre.

Iversen, T., \& Rosenbluth, F. (2006). The Political Economy of Gender: Explaining Cross-National Variation in the Gender Division of Labor and the Gender Voting Gap. American Journal of Political Science 50(1), 1-19.

Jakobsson, N., Hansen, T., \& Kotsadam, A. (2012). Er det en sammenheng mellom formell og uformell omsorg i Norge? [Is there a connection between formal and informal care in Norway?] Tidsskrift for Velferdsforskning, 15(3), 168-175.

Jakobsson, N., \& Kotsadam, A. (2010). Do Attitudes Toward Gender Equality Really Differ Between Norway and Sweden? Journal of European Social Policy, 20(2), 142-159.

Jakobsson, N., \& Kotsadam, A. (2011). Gender Equity and Prostitution: An Investigation of Attitudes in Norway and Sweden. Feminist Economics, 17(1), 31-58.

Jegermalm, M. \& Jeppsson Grassman, E. (2009). Patterns of Informal Help and Caregiving in Sweden: A Thirteen-Year Perspective. Social Policy \& Administration, 43(7) 681-701. 
Jeppsson Grassman, E., Whitaker, A., \& Larsson, A. T. (2009) Family as failure? The role of informal help-givers to disabled people in Sweden. Scandinavian Journal of Disability Research, 11(1), 35-49.

Johnson, R., \& Lo Sasso, A. (2000). The Trade-Off between Hours of Paid Employment and Time Assistance to Elderly Parents at Midlife. The Urban Institute Working Papers.

Kautto, M., Heikkilä, M., Hvinden, B., Marklund, S., \& Ploug, N. (Eds.). (1999). Nordic Social Policy: Changing Welfare States. London: Routledge.

Korpi, W. (2000). Faces of Inequality: Gender, Class, and Patterns of Inequalities in Different Types of Welfare States. Social Politics, 7(2), 127-191.

Kotsadam, A., \& Jakobsson, N. (2011). Do laws affect attitudes? An assessment of the Norwegian prostitution law using longitudinal data. International Review of Law and Economics, 31(2), 103-115.

Kotsadam, A. (2011). Does Informal Eldercare Impede Women's Employment? The Case of European Welfare States. Feminist Economics, 17(2), 121-144.

Kotsadam, A. (2012). The Employment Costs of Caregiving in Norway. International Journal of Health Care Finance and Economics, 12(4), 269-283.

Leigh, A. (2010) Informal care and labor market participation. Labour Economics, 17(1), 140-149.

Leira, A. (2006). Parenthood change and policy reform in Scandinavia, 1970s2000s. In A.-L. Ellingsæter, \& A. Leira, (Eds), Politicising Parenthood in Scandinavia: Gender Relations in Welfare States (chapter 2). Bristol (UK): The Policy Press.

Lingsom, S. (1994). Voksne barn - gamle foreldre. Aldring \& Eldre, 4.

Lilly, M. B., Laporte, A., \& Coyte, P. C. (2007). Labor Market Work and Home Care's Unpaid Caregivers: A Systematic Review of Labor Force Participation Rates, Predictors of Labor Market Withdrawal, and Hours of Work. The Milbank Quarterly, 85(4), 641-690.

Michaud, P.-C., Heitmueller, A., \& Nazarov, Z. (2010). A dynamic analysis of informal care and employment in England. Labour Economics, 17(3), 455-465. 
Ogg, J., \& Renaut, S. (2006). The support of parents in old age by those born 1945-1954: a European perspective. Ageing \& Society, 26(5), 723-743.

Pavalko, E., \& Artis, J. (2003). Explaining the Decline in Women's Household Labor: Individual Change and Cohort Differences. Journal of Marriage and Family, 65(3), 746-761.

Rauch, D. (2007). Is There Really a Scandinavian Social Service Model?: A Comparison of Childcare and Elderlycare in Six European Countries Acta Sociologica, 50(3), 249-269.

Rostgaard, T., \& Szebehely, M. (2012). Changing Policies, Changing Patterns of Care: Danish and Swedish Home Care at the Crossroads. European Journal of Ageing, 9(2), 101-109.

Rubery, J., Smith, M., Anxo, D., \& Flood, L. (2001). The Future European Labor Supply: The Critical Role of the Family. Feminist Economics, 7(3), 33-69.

Simonazzi, A. (2009). Care Regimes and National Employment Models. Cambridge Journal of Economics, 33(2), 211-232.

Spiess, K., \& Schneider, U. (2003). Interactions between Care-Giving and Paid Work Hours among European Midlife Women, 1994 to 1996. Ageing and Society, 23(1), 41-68.

Statistics Norway. (2010). Average numbers of assigned hours per week for users of home help and home nursing. Retrieved November 6, 2012, from Statistics Norway's Web site: www.ssb.no/pleie_en/tab-2011-0708-07-en.html.

Szebehely, M. (2005). Care as employment and welfare provision - child care and elder care in Sweden at the dawn of the 21st century. In H. M. Dahl, \& T. Rask Eriksen (Eds.), Dilemmas of Care in the Nordic Welfare State (pp. 80-97). Ashgate, Aldershot.

Szebehely, M. (2006). Informella hjälpgivare. In J. Vogel, \& L. Häll (Eds.), Äldres levnadsförhållanden. Stockholm: Statistics Sweden.

Wolf, D., \& Soldo, B., (1994). Married Women's Allocation of Time to Employment and Care of Elderly Parents. Journal of Human Resources, 29(4), 1259-1276. 


\section{Appendix 1. Tables}

Table A1. Variable description

\begin{tabular}{ll}
\hline Variable & Explanation \\
\hline Age & respondent age \\
Married & $=1$ if respondent is married or cohabiting \\
Employed & $=1$ if employed full- or part-time \\
Male & $=1$ if male \\
Capital & $=1$ if living in the capital (Oslo, Stockholm or \\
& Copenhagen) \\
High income & $=1$ if respondent earns >600 000 NOK/SEK/DKK per \\
& year \\
Low income & $=1$ if respondent earns <200 000 NOK/SEK/DKK per \\
High education & $=1$ if at least some university education \\
Low education & $=1$ if respondent only has elementary education or less \\
Care & $=1$ if respondent provides informal care to someone \\
Substantial care & $=1$ if respondent provides care $30 \mathrm{~h}$ or more per month \\
Carehours & Number of hours in informal care, truncated at 99 hours \\
per month \\
Parental care & $=1$ if respondent provides informal eldercare \\
Parental care & Number of hours in informal eldercare, truncated at 99 \\
hours & hours per month \\
Childcarehours & Number of hours in informal childcare, truncated at 99 \\
hours per month \\
$=1$ if respondent provides informal care to a child
\end{tabular}


Table A2. Descriptive statistics

\begin{tabular}{|c|c|c|c|c|}
\hline Variable & Norway & Sweden & Denmark & Pooled \\
\hline Age & $\begin{array}{l}41.809 \\
(13.839)\end{array}$ & $\begin{array}{l}45.049 \\
(13.275)\end{array}$ & $\begin{array}{l}46.183 \\
(13.100)\end{array}$ & $\begin{array}{l}44.187 \\
(13.572)\end{array}$ \\
\hline Married & $\begin{array}{l}0.673 \\
(0.469)\end{array}$ & $\begin{array}{l}0.693 \\
(0.462)\end{array}$ & $\begin{array}{l}0.737 \\
(0.441)\end{array}$ & $\begin{array}{l}0.611 \\
(0.488)\end{array}$ \\
\hline Employed & $\begin{array}{l}0.712 \\
(0.453)\end{array}$ & $\begin{array}{l}0.797 \\
(0.402)\end{array}$ & $\begin{array}{l}0.708 \\
(0.455)\end{array}$ & $\begin{array}{l}0.734 \\
(0.442)\end{array}$ \\
\hline Male & $\begin{array}{l}0.494 \\
(0.500)\end{array}$ & $\begin{array}{l}0.521 \\
(0.500)\end{array}$ & $\begin{array}{l}0.476 \\
(0.500)\end{array}$ & $\begin{array}{l}0.495 \\
(0.500)\end{array}$ \\
\hline Capital & $\begin{array}{l}0.158 \\
(0.365)\end{array}$ & $\begin{array}{l}0.178 \\
(0.383)\end{array}$ & $\begin{array}{l}0.216 \\
(0.412)\end{array}$ & $\begin{array}{l}0.183 \\
(0.388)\end{array}$ \\
\hline High income & $\begin{array}{l}0.104 \\
(0.306)\end{array}$ & $\begin{array}{l}0.079 \\
(0.269)\end{array}$ & $\begin{array}{l}0.101 \\
(0.301)\end{array}$ & $\begin{array}{l}0.096 \\
(0.294)\end{array}$ \\
\hline Low income & $\begin{array}{l}0.148 \\
(0.356)\end{array}$ & $\begin{array}{l}0.158 \\
(0.365)\end{array}$ & $\begin{array}{l}0.138 \\
(0.345)\end{array}$ & $\begin{array}{l}0.147 \\
(0.355)\end{array}$ \\
\hline High education & $\begin{array}{l}0.579 \\
(0.494)\end{array}$ & $\begin{array}{l}0.460 \\
(0.499)\end{array}$ & $\begin{array}{l}0.390 \\
(0.488)\end{array}$ & $\begin{array}{l}0.482 \\
(0.500)\end{array}$ \\
\hline Low education & $\begin{array}{l}0.061 \\
(0.239)\end{array}$ & $\begin{array}{l}0.124 \\
(0.330)\end{array}$ & $\begin{array}{l}0.112 \\
(0.315)\end{array}$ & $\begin{array}{l}0.096 \\
(0.294)\end{array}$ \\
\hline Care & $\begin{array}{l}0.447 \\
(0.497)\end{array}$ & $\begin{array}{l}0.377 \\
(0.485)\end{array}$ & $\begin{array}{l}0.488 \\
(0.500)\end{array}$ & $\begin{array}{l}0.441 \\
(0.497)\end{array}$ \\
\hline Substantial care & $\begin{array}{l}0.051 \\
(0.221)\end{array}$ & $\begin{array}{l}0.031 \\
(0.174)\end{array}$ & $\begin{array}{l}0.045 \\
(0.207)\end{array}$ & $\begin{array}{l}0.044 \\
(0.204)\end{array}$ \\
\hline Carehours & $\begin{array}{l}12.396 \\
(16.322)\end{array}$ & $\begin{array}{l}16.274 \\
(25.053)\end{array}$ & $\begin{array}{l}11.178 \\
(14.681)\end{array}$ & $\begin{array}{l}12.874 \\
(18.376)\end{array}$ \\
\hline Parentalcare & $\begin{array}{l}0.228 \\
(0.420)\end{array}$ & $\begin{array}{l}0.212 \\
(0.409)\end{array}$ & $\begin{array}{l}0.275 \\
(0.447)\end{array}$ & $\begin{array}{l}0.239 \\
(0.427)\end{array}$ \\
\hline Parentalcarehours & $\begin{array}{l}13.815 \\
(16.316)\end{array}$ & $\begin{array}{l}15.694 \\
(23.577)\end{array}$ & $\begin{array}{l}\begin{array}{l}11.591 \\
(14.476)\end{array}\end{array}$ & $\begin{array}{l}13.429 \\
(17.853)\end{array}$ \\
\hline Childcare & $\begin{array}{l}0.041 \\
(0.199)\end{array}$ & $\begin{array}{l}0.028 \\
(0.164)\end{array}$ & $\begin{array}{l}0.045 \\
(0.208)\end{array}$ & $\begin{array}{l}0.039 \\
(0.193)\end{array}$ \\
\hline Childcarehours & $\begin{array}{l}19.505 \\
(20.115)\end{array}$ & $\begin{array}{l}34.761 \\
(38.891)\end{array}$ & $\begin{array}{l}17.598 \\
(20.264)\end{array}$ & $\begin{array}{l}21.745 \\
(25.665)\end{array}$ \\
\hline
\end{tabular}




\section{Appendix 2. Question on care posed to the respondents}

Have you helped a family member, relative, friend, or neighbour who needs help in everyday life owing to long-term illness, disability, or old age at least once a month during the past year (e.g., with cleaning, paperwork, personal care, or going outside)?

$\square$ Yes, husband/wife/cohabitant/partner

$\square$ Yes, children

$\square$ Yes, parents/parents-in-law

$\square$ Yes, other relative, friend or neighbour

$\square$ No

$\square$ If yes, how many hours a month? 